\title{
Sodium content and food additives in major brands of Brazilian children's foods
}

\author{
Conteúdo de sódio e aditivos alimentares das maiores marcas \\ de alimentos destinados para crianças brasileiras
}

Antônio Zenon Antunes Teixeira ${ }^{1}$

${ }^{1}$ Instituto Federal de Educação, Ciência e Tecnologia de Goiás. Av.Universitária Vereador Vagner da Silva Qd 01, Lt 1-A Parque Itatiaia, 74968-755 Aparecida de Goiânia GO Brasil azteixei@gmail.com

\begin{abstract}
The objective of this paper is to evaluate the sodium content and additive usage in packaged food products targeted at Brazilian children. Commercial database and manufactures' websites were used to identify major brands of child-oriented foods. Samples were categorized as "children's foods" ( $n=214)$ and "infant's foods" ( $n=$ 86). Nutrition Facts labels were used to calculate the median Na content ( $\mathrm{mg} / \mathrm{serving}, \mathrm{mg} / \mathrm{kcal}$, and $\mathrm{mg} / 100 \mathrm{~g})$; the ingredient lists to note the use of food additives. The sodium content found in samples varied widely among brands. The amount of sodium was high (> $210 \mathrm{mg} / \mathrm{serving}$ ) in 20\% of the products. Sodium density exceeded $1 \mathrm{mg} / \mathrm{kcal}$ in $40 \%$ of the products with the savory foods had the highest densities. More than 30\% of the foods categories (corn snacks, filled biscuits, sliced loaf bread, and cereals) did not fulfill the 2014 sodium reduction targets. Food additives present in all children's foods varied from two to nine additives numbers. However, some products had incredible numbers of additives, such as instant noodles and mini cakes. Although some infants' foods categories were additives free, most products contained up to three numbers of additives. Continuing surveillance is crucial to evaluate the progress of salt reduction and to revise the maximum permissible limit of additives.
\end{abstract}

Key words Children's foods, Additives, Processed foods, Sodium
Resumo O objetivo deste trabalho é avaliar o teor de sódio e a utilização de aditivos em alimentos industrializados destinados às crianças no Brasil. Bancos de dados comerciais foram usados para identificar as principais marcas de alimentos. Foram classificadas como "alimentos para crianças" $(n=214) e$ "alimentos infantis" ( $n=$ 86). Os rótulos nutricionais foram usados para calcular a mediana de sódio ( $\mathrm{mg} / \mathrm{porção,} \mathrm{mg} / \mathrm{kcal}$ e $\mathrm{mg} / 100 \mathrm{~g}$ ) e a lista de ingredientes comprovou o uso de aditivos alimentares. $O$ teor de sódio encontrado em amostras variou entre as marcas. A quantidade de sódio foi elevada (> $210 \mathrm{mg} /$ porção) em $20 \%$ dos produtos. A concentração de sódio superior a $1 \mathrm{mg} / \mathrm{kcal} \mathrm{em} 40 \%$ dos produtos com os alimentos salgados representou as maiores quantidades. Mais de 30\% das categorias (salgadinho de milho, biscoitos recheados, pão de forma e cereais) não cumpriram as metas de 2014 de redução de sódio. Os aditivos presentes em alimentos de crianças variaram de dois a nove aditivos. No entanto, alguns produtos tiveram mais aditivos, tais como macarrão instantâneo e mini bolo. Alguns alimentos infantis estavam livres de aditivos, mas a maioria dos produtos continha até três. Um constante monitoramento é fundamental para avaliar o progresso na redução de sódio e no limite máximo admissivel de aditivos.

Palavras-chave Alimentos para crianças, Aditivos, Alimentos processados, Sódio 


\section{Introduction}

According to the Brazilian Institute of Geography and Statistics (IBGE) survey in 2009, one in three Brazilian children (5- to 9-years-old) was overweight ${ }^{1}$. Recently, the Health Ministry-IBGE revealed that $32 \%$ of children less than 2 -yearsold consumed soft drinks and artificial juices while $60 \%$ of them ate packaged of biscuits, cookies and filled cakes ${ }^{2}$. Moreover, the Federal University of São Paulo - Department of Pediatrics disclosed that $65 \%$ of children aged 9-36 months attending day care centers consumed instant noodles in their first year of lives ${ }^{3}$. The practice of this eating behavior has led a concern to the possible health risks due to the excess of sodium and additives present in processed foods. As stated by Polonia and Peres ${ }^{4}$, children are the most vulnerable group to the adverse risks of food additives as most of their diets contains additives particularly synthetic food colors.

Sodium is an essential nutrient to maintain the body fluid levels and to provide nerve signaling channels. However, excessive consumption in children is associated with obesity, hypertension and cardiovascular disease ${ }^{5}$. The Institute of Medicine (IOM) recommends that daily Dietary Adequate Intake (AI) for sodium: $1000 \mathrm{mg} / \mathrm{d}$ for children aged 1-3 years, $1200 \mathrm{mg} / \mathrm{d}$ for aged 4-8, $1500 \mathrm{mg} / \mathrm{d}$ for aged 9-13 years and less than 400 $\mathrm{mg} / \mathrm{d}$ for infants. IOM also defined daily Tolerable Upper Intake level (UL) for sodium at 1500 $\mathrm{mg}, 1900 \mathrm{mg}$ and $2200 \mathrm{mg}$ for children aged 1-3, 4-8 and 9-13 years ${ }^{6}$. Although a small amount of sodium naturally presents in most foods, most of the sodium in the diet comes from salt added to restaurants and packaged supermarket foods.

Additives are substances intentionally added to foods for various reasons, such as to improve taste, texture and appearance, as well as to preserve foods. However, a consumption exceeds the Acceptable Daily Intake (ADI) may cause adverse health effects such as brain cancer, irritability, sleep disturbance, and hyperactivity in the long term ${ }^{7-9}$. The ADI is the number of $\mathrm{mg} / \mathrm{kg}$ of body weight $(\mathrm{mg} / \mathrm{kg} \mathrm{bw})$ per day that can be ingested without possible health risks. Although the Brazilian legislation requires food industries to list all additives on the food labels ${ }^{10}$, the additive amount used is not necessarily declared.

The objectives of this study are to evaluate the sodium content and the additives usage obtained from Nutritional Facts labels of food products sold in Brazil in the period of 2014 which appeal to children.

\section{Methods}

A commercial database of the biggest supermarket retails (Grupo Pão de Açúcar) and manufacturers' websites were used to identify the major brands of children-oriented foods. Data collection was performed from March to June 2014. Then, we exclude children's foods products that are easily perceived for additives content such as candies/gums, gelatins, lollipops and artificial juices. The final 300 products were identified for additives and sodium content analysis. The products were classified into two categories: 1 ) children's foods $(\mathrm{n}=124)$ comprised eight subcategories: biscuits/cookies, corn snacks, bread/ mini cakes, cereals, instant noodles, frozen foods (foods that require minimal preparation such as breaded chicken, pizza, lasagna, hamburger, bologna, and sausage), milk/flavored milk, yogurts/fermented milk, and petit-suisses and 2) infant's foods $(\mathrm{n}=86)$ comprised 4 sub-categories: purred baby foods, infant formulas, nutritive foods (powder and complementary foods for toddlers), and porridge/cereals. Specific indicators of children's foods and criteria for inclusion in the samples were: foods that are marketed to appeal children by the use of cartoon images, plays or colors, games and advertisings with children. Infants' foods were identified in mothers and babies section of the commercial website.

The sodium content (in $\mathrm{mg}$ ) was computed per serving, calories ( $\mathrm{kcal}$ ) and $100 \mathrm{~g}$ of food from the Nutrition Facts labels. To determine the high sodium levels per serving, we used the table of daily recommended serving for children ${ }^{11}$ and Elliot and Conlon's methodology ${ }^{12}$. Only three food groups were considered: 1) grain (cereal), 2) meat and alternatives and 3) milk and derivatives while fruit and vegetable categories were excluded due to their small contents. There is a total of seven, eight and ten daily serving opportunities to ingest sodium for children aged 1-3, 4-8 and 9-13 years respectively. Then, per-serving limit of sodium intake can be determined. Children aged 1-3 have seven servings to ingest their AI of 1000 $\mathrm{mg}$ of sodium but not exceed the UL of $1500 \mathrm{mg}$, corresponding to $140-210 \mathrm{mg} / \mathrm{serving}$. Children aged 4-8 and 9-13 year have relatively similar results, giving $150-237 \mathrm{mg} /$ serving and 150-220 $\mathrm{mg} /$ serving correspondingly. Then, a product is deemed to have a high level of sodium if it exceeds $210 \mathrm{mg} /$ serving. IOM dietary reference intake also defined that sodium $>210 \mathrm{mg} /$ serving as a high level for children aged 1-3 years ${ }^{13}$.

The use of sodium density $(\mathrm{mg} / \mathrm{kcal})$ has been proposed as a way to compare the sodium 
content of foods with the same amount of calories because sodium and kcal consumption are highly positively correlated ${ }^{14}$. When the required daily caloric intake is $2000 \mathrm{kcal}$, a food product is considered to have high-level sodium if it surpasses $1 \mathrm{mg} / \mathrm{kcal}$.

Children's foods were compared to the 2014 government salt reduction targets, the Food and Drug Administration (FDA) "healthy" label claim and the National Health Surveillance Agency (Anvisa) "low sodium" attribute. To facilitate these comparisons, sodium content was converted to the $100 \mathrm{~g}$ standard serving size.

Data input and analysis were carried out using Excel 2013 (Microsoft Corp.). The median of the $\mathrm{Na}$ content was calculated in $\mathrm{mg} /$ serving, $\mathrm{mg} /$ $\mathrm{kcal}, \mathrm{mg} / 100 \mathrm{~g}$. The median of the label serving size was computed to be compared to the current regulation. The maximum and the minimum $\mathrm{Na}$ content and label serving size were used to analyze the samples dispersion. The sodium content in $\mathrm{mg} /$ label serving was classified as high $(>210$ $\mathrm{mg}$ ), medium (>140 and $\leq 210 \mathrm{mg}$, and low ( $\leq$ $140 \mathrm{mg}$ ) corresponding to per-serving limit of sodium intake for children aged 1-3 (140-210 $\mathrm{mg}$ ). The differences among the food categories were analyzed by Chi square test. The $P$ value $<$ 0.05 was considered statistically significant.

Food additives present in child-oriented products were classified according to their functional classes: antioxidants, coloring agents, flavoring agents, preservatives, texturing agents, etc. The products were analyzed for which the most important additives present in processed foods and discuss the potentially toxic and diseases caused by consumption of these foods.

\section{Results and discussions}

\section{Sodium content}

Table 1 details the median sodium content of infants' and children's foods. In children's foods categories, the median varied between $22 \mathrm{mg} /$ serving in petit-suisses to $1.410 \mathrm{mg} / \mathrm{serving}$ in instant noodles. Approximately $20 \%$ of the products (60 of 300) were high in sodium, exceeded $210 \mathrm{mg} / \mathrm{serving}$ in which over half of corn snacks contributed the high amounts. High variation of sodium levels among brands was observed, for example, in corn snacks (label serving size $25 \mathrm{~g}$ ), the content varied from $99 \mathrm{mg} / \mathrm{serving}$ to $319 \mathrm{mg} /$ serving, the difference of the content between the less and the highest levels were $200 \%$. However, the large variations of the products' serving size also contributed the variation in the $\mathrm{Na}$ content in $\mathrm{mg} / \mathrm{serving}$ such as in yogurt/fermented milk. In yogurts/fermented milk category for example, the median of the labels serving size $(100 \mathrm{~g})$ were far below of the current law $(200 \mathrm{~g})$. A similar circumstance was published by Kraemer et. al. ${ }^{15}$ in their study on processed foods for snacks marketed for children and adolescents in Brazil. The authors described that $14 \%$ of all the processed foods assessed did not comply the current serving size rule that makes the customers have difficulty to compare the $\mathrm{Na}$ content of similar foods. In infants' foods categories, the median sodium contents ranged from $12 \mathrm{mg} /$ serving in pureed fruit to $367 \mathrm{mg} / \mathrm{serving}$ in baby pureed - meat/legume based. While in sub-categories porridge/cereals, nutritive foods, and pureed fruit were low in sodium; savory pureed baby dinners are conspicuous for promoting foods high in sodium. This category was dominated by particular brand wherein one product contained sodium as much as 420 $\mathrm{mg} / \mathrm{serving}$. In the case of infant formula, according to Anvisa ${ }^{16}$, the Nutrition Facts labels should be declared per $100 \mathrm{~g}$, and there is no need for indication of the serving size and the recommended Daily Value (\% DV). Figure 1 presents the summary statistics for the children's and infants' food categories (except infant formula) into high, medium and low $\mathrm{Na}$. Of the 281 food products, it was found that $22 \%$ of the samples had high $\mathrm{Na}$ while 23 and $55 \%$ of the foods contained medium and low Na respectively. We observed that the sodium levels in corn snacks, instant noodles and frozen foods were exceeded the recommended maximum per-serving limit ( $210 \mathrm{mg}$ ).

The median sodium density of 118 food products ( $40 \%$ of the samples) exceeded $1 \mathrm{mg} /$ $\mathrm{kcal}$. Sodium density was high in corn snacks $(1,8$ $\mathrm{mg} / \mathrm{kcal})$, frozen foods $(3,0 \mathrm{mg} / \mathrm{kcal})$ and instant noodles $(3,8 \mathrm{mg} / \mathrm{kcal})$. Infants' diets contained a reasonable level of sodium, except sub-categories pureed baby food (meat/legume based), the densities were $1,3-1,8 \mathrm{mg} / \mathrm{kcal}$. Infant formulas are subject to special regulations ${ }^{17}$ in which the sodium content of all samples was within the legislation, between $20-60 \mathrm{mg} / 100 \mathrm{kcal}$. The mean densities of sweet foods such as biscuits/cookies, yogurts, and bread/mini cakes categories except for cereals, indicated low and moderate sodium per kilocalorie. However, it is important to highlight that foods high in sugar are relatively low in sodium per kilocalorie. Therefore, the measure of the low sodium content as healthy foods should be interpreted carefully ${ }^{18}$. 


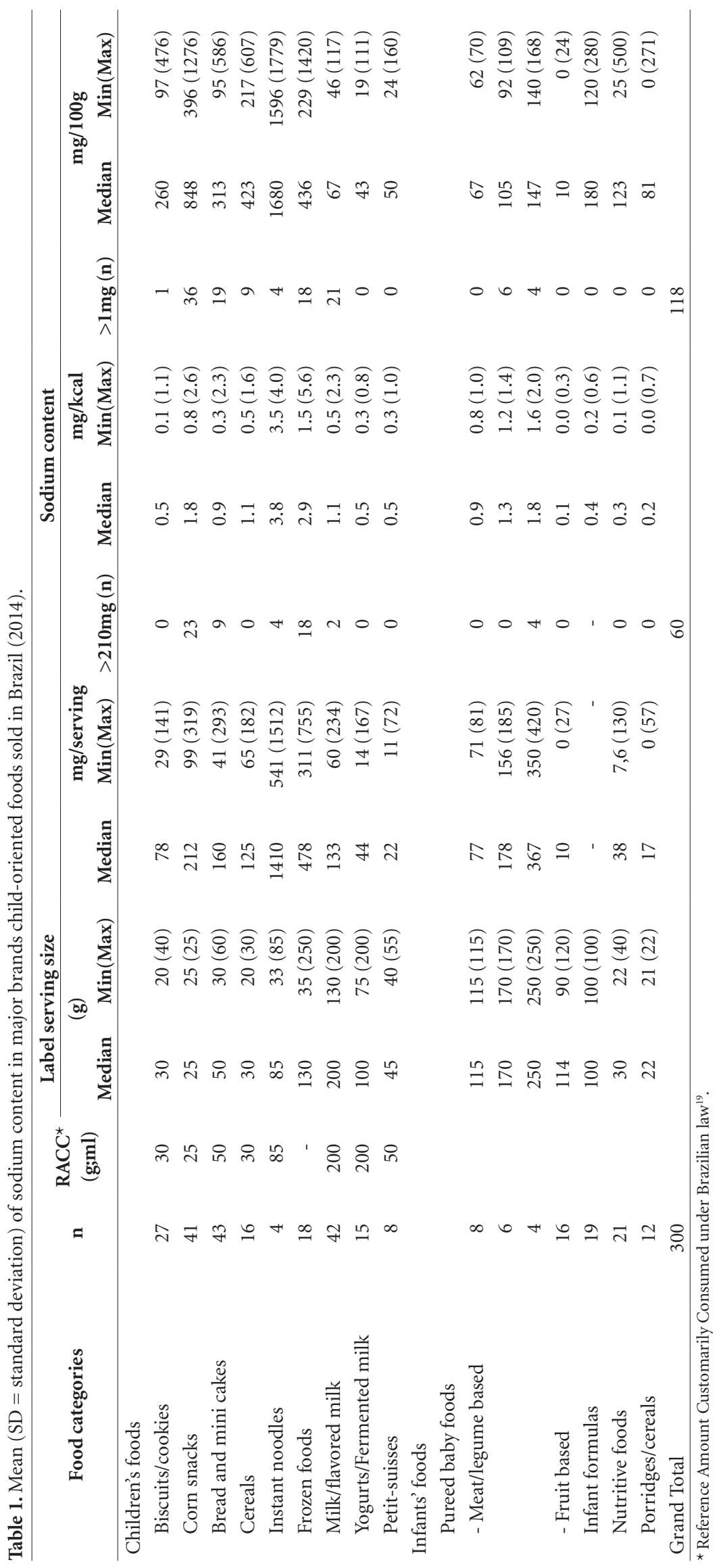




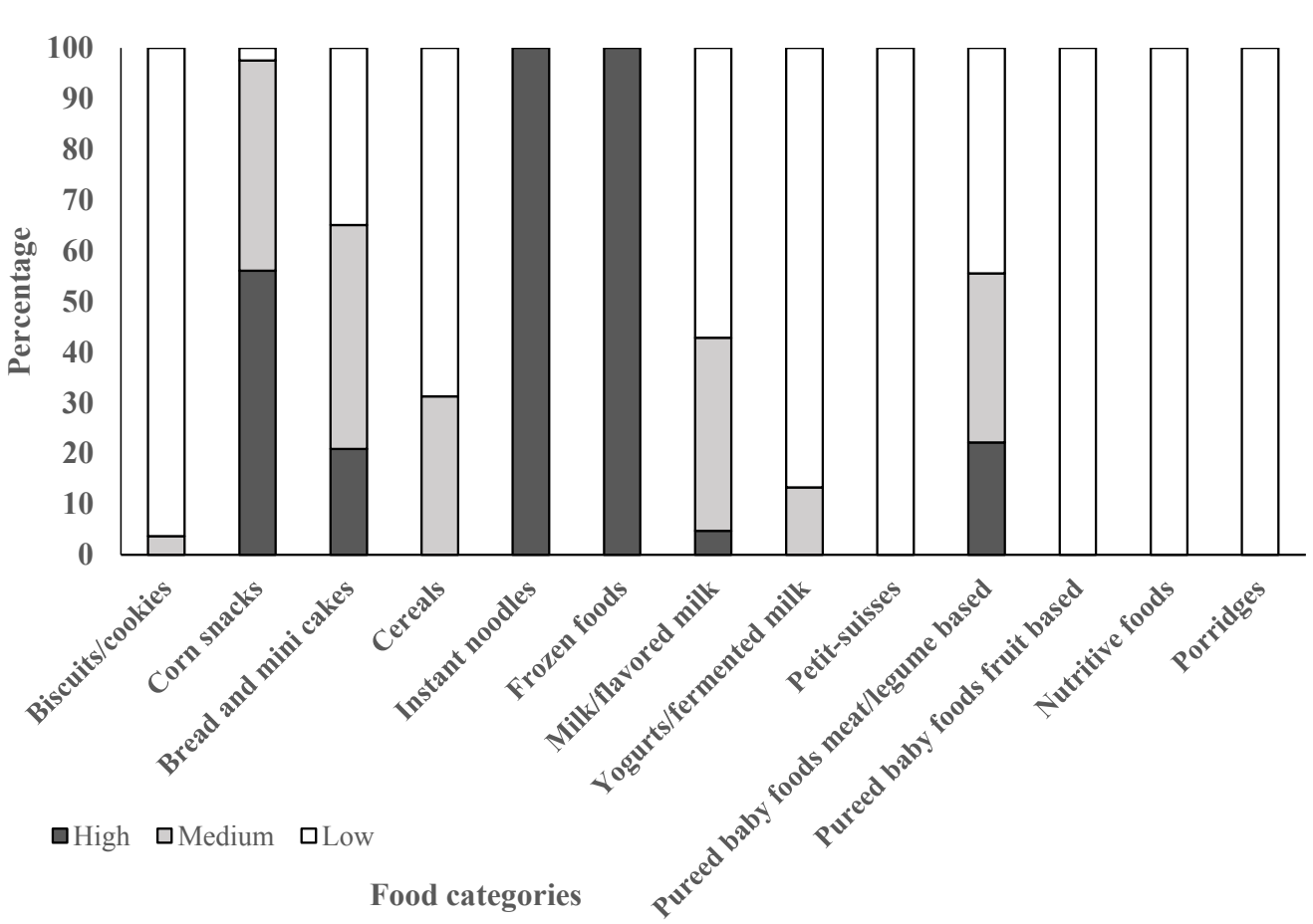

Figure 1. The classification of the sodium content in $\mathrm{mg} / \mathrm{label}$ serving for 13 food categories, $\mathrm{n}=281$ (infant formula was excluded). The Na was classified as high $(>210 \mathrm{mg})$, medium ( $>140$ and $\leq 210 \mathrm{mg})$, and low $(\leq 140$ $\mathrm{mg})$. The classification was significantly different among the food categories $\left(X^{2}\right.$, two-tailed test, $\left.\mathrm{p}<0.05\right)$.

FDA has set condition for the use of "healthy" food label claim. Sodium limits being "healthy" are $<480 \mathrm{mg} /$ serving for individual food or $<$ $480 \mathrm{mg} / 50 \mathrm{~g}$ if the Reference Amount Customarily Consumed (RACC) is small $(\leq 30 \mathrm{~g})$ and $<600$ $\mathrm{mg} /$ serving for meals and main dishes ${ }^{20}$. Still, the content for this claim should be less for child-oriented foods since children's daily maximum limit for salt consumption are less than adults. Instant noodles were deemed to be unhealthy meals with salt content $>600 \mathrm{mg} / \mathrm{serving}$. Although corn snacks were found to be "healthy" with 424 $\mathrm{mg} / 50 \mathrm{~g}$, the serving size two tea cups $(30 \mathrm{~g})$ may not consistently respected. It is more likely for a child to consume the entire pack ( $60 \mathrm{~g}$ of Skiny, for example) than the recommended serving size. Anvisa also established the "low sodium" attribute when the products contain less than 120 $\mathrm{mg} / 100 \mathrm{~g}^{21}$. In children's foods category, the low sodium could be found in sweet food products, such as milk/flavored milk (Table 1).

In 2010, the Health Ministry and food industries launched salt reduction campaign and set the reduction targets for the periods 2011-2016 22,23 . It was estimated that industries have reformulated voluntarily a variety of product groups which resulted in a salt reduction (Table 2 ). The results showed that sweet biscuits and instant noodles have met the targets for 2014 while more than $30 \%$ of four food categories (sweet filled biscuits, corn snacks, sliced loaf bread, and cereals) were unable to fulfill them. According to the Brazilian Institute of Consumer Defense (Idec), the targets were set high, and, therefore, most industries did not need to reduce the sodium content of their products to fulfill the agreement. In order to obtain the direct impact in public health, the large manufacturers particularly, should make efforts towards salt reduction ${ }^{24}$. In addition, the increased monitoring of the accuracy of food labels is recommended. Nutrition Facts could play an important role in the prevention of many chronic diseases if they were accurate since the consumers use this information to make their dietary choices ${ }^{25}$. Still, some studies showed the differences between the label and the laboratory values. Ribeiro et al. reported that $75 \%$ of food products investigated and tested using flame 
Table 2. A comparison the sodium content of children's foods products and the government 2014 salt reduction targets.

\begin{tabular}{|c|c|c|c|c|}
\hline \multirow[t]{2}{*}{ Categories } & \multirow{2}{*}{$\begin{array}{l}\text { Annual salt } \\
\text { reduction set by government }\end{array}$} & \multirow{2}{*}{$\begin{array}{l}2014 \text { Targets } \\
\mathrm{mg} / 100 \mathrm{~g}\end{array}$} & \multicolumn{2}{|c|}{$\begin{array}{c}\text { Products did not meet the } \\
2014 \text { targets }\end{array}$} \\
\hline & & & $\mathbf{n}$ & $\%$ \\
\hline \multicolumn{5}{|l|}{ Biscuits/cookies: } \\
\hline - Sweet biscuits & $7,5 \%$ from 2011 until 2014 & 359 & - & - \\
\hline - Sweet filled biscuits & $8,5 \%$ from 2011 until 2014 & 265 & 7 of 21 & 33 \\
\hline Corn snacks & 8,5\% from 2011 until 2016 & 903 & 14 of 41 & 34 \\
\hline \multicolumn{5}{|l|}{ Bread and cakes: } \\
\hline - Sliced loaf bread & $10 \%$ from 2011 until 2014 & 522 & 3 of 8 & 37 \\
\hline - Small roll bread & 10\% from 2011 until 2014 & 430 & 1 of 8 & 12 \\
\hline - Mini filled cakes & 7,5\% from 2011 until 2014 & 204 & 6 of 27 & 22 \\
\hline Cereals & $\begin{array}{l}7,5 \% \text { in } 2012 \text { and } 2013 \\
15 \% \text { in } 2014 \text { and } 2015\end{array}$ & 455 & 6 of 16 & 37 \\
\hline Instant noodles & $30 \%$ in 2011 and 2012 & 1920 & - & - \\
\hline
\end{tabular}

photometry had Na laboratory values exceeding $20 \%$ of the Nutrition Facts values ${ }^{26}$. A survey conducted by Idec also identified food products had sodium greater than a tolerance value $(20 \%)$ of the declared information ${ }^{27}$.

\section{Food additives}

In Brazil, food additives are divided into 23 functional classes: acids, acidity regulators, antioxidants, antifoaming agents, anti-humectants, bulking agent, colorants, color retention agents, emulsifiers, firming agents, flavors, flavor enhancers, flour treatment agents, foaming agents, gelling agents, glazing agents, humectants, preservatives, raising agents, sequestrants, stabilizers, sweeteners, and thickeners ${ }^{28}$. Though, Anvisa allows additives to be mentioned in two or more classes, for instance, sorbic acid (E200) can be classified as preservative, antioxidant and stabilizer. A total of 300 supermarket products were analyzed for their ingredients list. The results revealed that in children's foods were found at least one or two additives. Food categories biscuits/ cookies, corn snacks, cereals, frozen foods, milk/ flavored milk and yogurt/petit suisse contained 2-9 additives. For some foods, there are incredible numbers of additives can be found, such as instant noodles (11 additives) and mini cakes (16 additives). Double chocolate cake (Bauducco), for instance, contained three preservatives (sorbic acid, calcium proprionate, and potassium sorbate), four emulsifiers (lecithin, mono and diglycerides of fatty acids, polyglycerol polyricinoleates and glyceryl monostearate), four raising agents (sodium bicarbonate, sodium acid pyrophosphate, monocalcium phosphate and calcium carbonate), gelling agent (pectin), humectants (glycerin and sorbitol), acid (citric acid) and flavor. Corn snack Swiss cheese (Cheetos) had three flavor enhancers (monosodium glutamate, disodium inosinate and disodium guanylate), flavor, anti-humectant (silicon dioxide) and colorant. Chocolate wafer truffle (Toddy) and brigadeiro flavoured wafer (Mabel) had three colorants (tartrazine, red 40 and caramel IV). Though some infants' foods categories were additives free, some products contained up to three numbers of additives. Anvisa stated specific regulation for additives used in infants' foods, include the allowable food additives, and the maximum levels use in cereals ${ }^{29}$, baby purred ${ }^{30}$ and infant formula ${ }^{31}$. In our samples, additives used in infants' foods were according to the current policies. Flavor and natural coloring agents were added into porridges. Antioxidant ascorbic acid and citric acid were prevalent in pureed baby foods and most commonly added in nutritive foods were flavors, emulsifiers (lecithin) and thickener (carrageenan and guar gum). The similar study revealed that the most additives used in processed foods were lecithin, citric acid and artificial dyes ${ }^{32}$.

Effect of food additives is dose related and cumulative $^{8}$. It means the more additives children eat, the more likely they are affected. As a result, a study of the quantitative relationship can be valuable in assessing the potential hazard of a chemical as a food additive ${ }^{33}$. The legislation requires that additives can only be used by food industries when it is explicitly set in legislation cor- 
Table 3. The most important food additives used in child-oriented products with their respective ADI quantities $(\mathrm{mg} / \mathrm{kg} \mathrm{bw})$.

\begin{tabular}{|c|c|c|}
\hline E Number - Name of Additives & Food Categories & $\mathrm{ADI}^{(28)}$ \\
\hline \multicolumn{3}{|l|}{ Preservatives: } \\
\hline 200-sorbic acid & Mini cakes & 25 \\
\hline 202-potassium sorbate & Mini cakes, yogurts, and petit-suisses & 25 \\
\hline 250-sodium nitrite & Frozen foods (bologna and sausage) & 0,1 \\
\hline 251-sodium nitrate & Frozen foods (bologna and sausage) & 0,1 \\
\hline 282-calcium propionate & Bread and mini cakes & \\
\hline \multicolumn{3}{|l|}{ Food colors: } \\
\hline 102-tartrazine & Wafer biscuits and mini cake Patata Patati & 7,5 \\
\hline 110-sunset yellow & $\begin{array}{l}\text { Corn snacks nacho cheese, mini cake vanilla } \\
\text { flavor, and cereal fruit loops }\end{array}$ & 2,5 \\
\hline 129 -red 40 & Wafer biscuits & 7 \\
\hline 133-brilliant blue & Cereal fruit loops and mini cakes & 10 \\
\hline 150d-caramel IV & Chocolate filled biscuits and wafer biscuits & 200 \\
\hline \multicolumn{3}{|l|}{ Flavor enhancers: } \\
\hline 621-monosodium glutamate & $\begin{array}{l}\text { Corn snacks, instant noodles, frozen foods } \\
\text { (chicken nugget) }\end{array}$ & - \\
\hline 627-disodium guanylate & Corn snacks, instant noodles & - \\
\hline 631-disodium inosinate & Corn snacks, instant noodles & - \\
\hline \multicolumn{3}{|l|}{ Emulsifiers: } \\
\hline 322-lecithins & Biscuits, bread, flavored milk & - \\
\hline 471- mono and diglycerides of fatty acids & Biscuits, bread, corn snacks & - \\
\hline
\end{tabular}

responding to their categories respective to their functions and usage limits ${ }^{28}$. Table 3 compiled the most important food additives predominantly present in the samples products, either based on the high consumption or the additives with the most adverse effects reported.

Preservatives are used in foods with objective to prevent food deterioration caused by microorganism or enzymes. There were five preservatives most added in product samples: sorbic acid (E200), potassium sorbate (E202), sodium nitrite (E250), sodium nitrate (E251) and calcium propionate (E282). Sorbic acid, most present in bread and mini cake, is the molecule base of three major antimicrobials: potassium, calcium and sodium sorbate, the last mentioned is banned in the United Kingdom but it is legal in Brazil. Some studies indicated that the conjugated double bonds present in sorbic acid's structure as being prone to nucleophilic attack, turning it into a mutagenic compound ${ }^{34}$, such when sorbic acid comes into contact with nitrite ${ }^{35}$ or when interact with a various amine ${ }^{36}$. Potassium sorbate, commonly added to mini cake, yogurt, and petit suisse, is also genotoxic to human peripheral blood lymphocytes at $1000 \mathrm{mg} / \mathrm{mL}^{37}$. Yet Jung et al. ${ }^{38}$ specified that sodium sorbate is mutagenic as be- ing easily oxidizable that leading to the formation of mutagenic compound (4,5-oxohexanoate) but, sorbic acid and potassium sorbate are not mutagenic. Sodium nitrite and nitrate are used to preserve the red color in meat products and also to protect against the microorganisms. The adverse effects of these additives were associated to methemoglobinemia ${ }^{39}$ and brain cancer ${ }^{7}$. Methemoglobinemia is a blood disorder in which an abnormal amount of methemoglobin (a form of hemoglobin) is produced. Consequently, with methemoglobinemia, the ability of hemoglobin to carry oxygen is significantly reduced ${ }^{34}$. Unfortunately, some studies demonstrated that the nitrate and nitrite levels of sausages in market exceeded the permissible limits ${ }^{40}$. The last preservative, calcium propionate is used particularly in bakery products. Little studies regarding to the calcium propionate toxicity but it was associated to irritability, restlessness, inattention and sleep disturbance in some children ${ }^{8}$.

Dyes are added to alter or confer colors to food. Anvisa legalizes eleven artificial food colors: tartrazine (E102), sunset yellow (E110), azorubine (E122), amaranth (E123), ponceau 4R (E124), erythrosine (E127), red 40 (E129), patent blue (E131), indigotine (E132), brilliant 
blue (E133) and fast green (E134). Some dyes are banned in some countries, but legally used in other countries. For instance, amaranth, azorubine or erythrosine are banned in the US but are legal in Brazil and other countries. In children's foods, we found the presences of sunset yellow, tartrazine, red 40, brilliant blue and caramel IV (Table 3). Tartrazine, sunset yellow and red 40 are member of azo group. The azo group represents various colors and all display the functional group $\mathrm{N}$ $=\mathrm{N}$. Tartrazine, according to Carocho et al. ${ }^{34}$, is probably one of the most controversial dye, with some studies classifying it as a DNA binder, toxic to human lymphocytes, a contributor to primary biliary cirrhosis, lipid peroxidation promoter by production of malondialdehyde, and reducer of superoxide dismutase and glutathione peroxidase in mice $(500 \mathrm{mg} / \mathrm{kg})$. However, some studies claimed that tartrazine does not cause harmful effect when ADI of $7.5 \mathrm{mg} / \mathrm{kg}$ is respected ${ }^{41}$.

Sunset yellow has good stability in the presence of light, heat and acid, but it can cause allergies and stomach problems and hyperactivity in children when combined with sodium benzoate9. The European Union countries such as Austria, Finland, and Norway prohibit its application in foods. Another azo, Red 40 is not genotoxic ${ }^{42}$. However, the previous study claimed that this dye caused nuclear DNA migration in the mouse ${ }^{43}$. Lucová et al. ${ }^{44}$ also disclosed that children consumed lollipops contain brilliant blue is dangerous because this color disrupted cell metabolism when entering the bloodstream through the lingual mucosa. Even though the regulation has established the maximum limit unluckily, one research showed that the concentration of tartrazine exceeded the maximum limit in gelatin and powder juice ${ }^{45}$. Another study involving eight artificial colors (E102, 110, 123, 124, 127, 129, 132 and E133) mentioned that $37 \%$ of chewing gums and $71 \%$ of colored cereals contained artificial dyes above the maximum limit ${ }^{42}$. One natural dye, caramel IV is a controversial color. It is a water-soluble food coloring and made by heat treatment of sugar. There are four classes of caramel color (Caramel I, II, III, and IV). A National Toxicology Program of the United Stated reported that class IV caramel (produced in the presence of both sulfite and ammonium compound) may cause cancer and can increase the incidence of certain lung tumors due to the byproducts formation of these compounds called 4-methylimidazole $(4-\mathrm{MEI})^{46}$. Though, FDA claims that caramel III and IV are not posing those risks if they are consumed at permitted levels ${ }^{47}$. The ADI of caramel IV is $200 \mathrm{mg} / \mathrm{kg}$ body weight which means $6 \mathrm{~g} / \mathrm{d}$ for a child's weight $30 \mathrm{~kg}$. Anvisa revealed that caramel IV intake of young Brazilian does not exceed the ADI, with an average $6.2 \mathrm{~g} / \mathrm{d}$, the number was calculated based on soft drink consumption ${ }^{48}$. Though, caramel IV is not only added in colas but is also found in chocolate filled biscuits, wafers, and powder juice.

Flavor enhancers are used in foods to produce the desired taste. The most used flavor enhancers are monosodium glutamate (E612), disodium inosinate (E631) and disodium guanylate (E627). These flavors were most found in corn snacks, instant noodles and frozen foods (Table 3). Monosodium glutamate (MSG) is sodium salt of glutamic acid. The adverse effects associated with MSG consumption included headache, numbness, nausea and chest pain ${ }^{49}$. Though, Food and Agriculture Organization (FAO) of the United Nations, World Health Organization (WHO) and the Scientific Committee for Food considered that MSG could be consumed without any concern ${ }^{34}$. MSG can be added in foods in accordance with good manufacturing practice at a level not higher than is necessary to achieve the intended products (quantum satis) ${ }^{50}$. It is important to note that MSG produces umami taste (savory flavor) and is highly palatable. Consequently, overeating can contribute to obesity and diseases associated with obesity. Disodium inosinate and disodium guanylate were used in conjunction with MSG in corn snacks and instant noodle. These two additives are less researched. However, the adverse effects of these additives in children have been claimed ${ }^{31}$.

Lecithins and mono and diglycerides of fatty acids are quantum satis status, most added into foods as stabilizers and emulsifiers. Stabilizers are added to maintain a homogeneous dispersion of two or more immiscible substances in food while emulsifiers are used to maintain a homogeneous mixture of two or more immiscible phases in food. No report about toxicity related to these additives.

\section{Conclusion}

$20 \%$ of the observed product had the Na content higher than $210 \mathrm{mg} / \mathrm{serving}$. Most high level Na was found in savory products of children's and infants' foods. Also, it presented in some non-savory foods likes bread/mini cakes category. Since the labels serving size varied for the same food category, the calculation of sodium density in $\mathrm{mg} / \mathrm{kcal}$ was proposed. $40 \%$ of the products 
had sodium density level higher than $1 \mathrm{mg} / \mathrm{kcal}$. Though, sweet foods contained low $\mathrm{Na}(<1 \mathrm{mg} /$ $\mathrm{kcal}$ ) for biscuits/cookies, yogurts, and petits-suisses, it is important to emphasize that foods with less sodium cannot always be interpreted as healthy because foods that are high in sugar and fats are relatively low in sodium per kilocalorie. In respect of food additives, it was analyzed that all products contained additives except in some infants' products. Studies in some products also showed that the additives concentrations exceeded the maximum limits, and the sodium content was greater than the label value. Therefore, increased surveillance is crucial to evaluate the progress of sodium reduction, the compliance of the labels serving size, and the maximum permissible limit of additives to protect public health and consequently can reduce the healthcare costs.

\section{References}

1. Instituto Brasileira Geografia e Estatística (IBGE) Pesquisa de Orçamento Familiares 2008-2009: Antropometria e estado nutricional de crianças, adolescentes e adultos no Brasil. [cited 2014 Jan 15]. Available from: http://www.ibge.gov.br/home/estatistica/ populacao/condicaodevida/pof/2008_2009_encaa/ pof_20082009_encaa.pdf.

2. Instituto Brasileira Geografia e Estatística (IBGE). Pesquisa Nacional de Saúde 2013. [cited 2014 Jan 15]. Available from: http://www.ibge.gov.br/home/estatistica/populacao/pns/2013/default_microdados.shtm.

3. Toloni MH, Longo-Silva G, Konstantyner T, Taddei AC. Consumption of industrialized food by infants attending child day care centers. Rev Paul Pediatr 2014; 32(1):37-43.

4. Polonia MLT, Peres F. Consumo de aditivos alimentares e efeitos à saúde: desafi os para a saúde pública brasileira. Cad Saude Publica 2009; 25(8):1653-1666.

5. He F, MacGregor G. A comprehensive review on salt and health and current experience of worldwide salt reduction programmes. J Hum Hypertens 2008; 23(6):363-384.

6. Institute of Medicine. Dietary Reference Intakes for Water, Potassium, Sodium, Chloride, and Sulfate. Washington: The National Academies Press, 2004. [cited 2014 Jan 20]. Available from: https://fnic.nal.usda.gov/sites/ fnic.nal.usda.gov/files/uploads/water_full_report.pdf.

7. Preston-Martins S, Pogoda JM, Mueller BA, Holly EA, Lijinsky W, Davis RL. Maternal consumption of cured meats and vitamins in relation to pediatric brain tumors. Cancer Epidemiol Biomarkers Prev 1996; 5(8):599-605.

8. Dengate S, Ruben A. Controlled trial of cumulative behavioural effects of a common bread preservative. $J$ Pediatr Child Health 2002; 38(4):373-376.
9. McCann D, Barret A, Cooper A, Crumpler D, Dalen L, Grimshaw K, Kitchin E, Lok K, Porteous L, Prince E, Sonuga-Barke E, Warner JO, Stevenson J. Food additives and hyperactive behavior in 3-year-old and 8/9-year-old children in community: a randomized, double blind, placebo-controlled trial. Lancet 2007; 370(9598):1560-1567.

10. Agência Nacional de Vigilância Sanitária (ANVISA). Resolução RDC 259, de 2002: Aprova o regulamento técnico sobre rotulagem de alimentos embalados [cited Feb 12]. Available from: http://portal.anvisa.gov.br/wps/ wcm/connect/36bf398047457db389d8dd3fbc4c6735/ RDC_259.pdf?MOD=AJPERES.

11. Health Australia. Recommended number of serves for children, adolescents and toddler [cited $2014 \mathrm{Feb} 22$ ]. Available from: https://www.eatforhealth.gov.au/ food-essentials/how-much-do-we-need-each-day/recommended-number-serves-children-adolescents-and.

12. Elliot CD, Conlon MJ. Toddler foods, children's foods: assessing sodium in packaged supermarket foods targeted at children. Public Health Nutr 2010; 14(3):490498.

13. Maalouf J, Cogswell ME, Gunn JP, Merrit R. Sodium content of commercial baby and toddler foods. Circulation 2013; 127:AP253.

14. Lee AK, Scieb LJ, Yuan K, Maalouf J, Gillespie C. Sodium content in packaged foods by census division in the US, 2009. Prev Chro Dis 2015; 12:E43.

15. Kraemer MVS, Oliveira RC, Gonzales-Chica DA, Proença RPC. Sodium content on processed foods for snacks. Public Health Nutr 2015; 19(6):967-975.

16. Agência Nacional de Vigilância Sanitária (ANVISA). Informe Técnico $N^{o} 36$ de 2008. [cited 2014 Nov 8]. Available from: http://portal.anvisa.gov.br/wps/content/Anvisa+Portal/Anvisa/Inicio/Alimentos/Publicacao+Alimentos/IT+N+36. 
17. Agência Nacional de Vigilância Sanitária (ANVISA). Resolução RDC 44, de 2011: O regulamento técnico para fórmulas infantil de seguimento para lactentes e crianças de primeira infância [cited 2015 Feb 12]. Available from: http://portal.anvisa.gov.br/wps/wcm/ connect/b11b30804aaa974f9effde4600696f00/Resolucao_RDC_n_44_de_19_de_setembro_de_2011.pdf?MOD $=$ AJPERES.

18. Gillespie C, Maalouf J, Yuan K, Cogswell ME, Gunn JP, Levings J.. Sodium content in major brands of US packaged foods, 2009. Am J Clin Nutr 2015; 101(2):344-353.

19. Agência Nacional de Vigilância Sanitária (ANVISA). Resolução RDC 359, de 2003: Aprova regulamento técnico de porções de alimentos embalados para fins de rotulagem nutricional [cited $2016 \mathrm{Jul} 22$ ]. Available from: http://bvsms.saude.gov.br/bvs/saudelegis/anvisa/2003/anexo/anexo_res0359_23_12_2003.pdf.

20. Food and Drug Administration (FDA). Guidance for Industry: A Food Labeling Guide [cited 2014 Oct 10]. Available from: http://www.fda.gov/Food/GuidanceRegulation/GuidanceDocumentsRegulatoryInformation/LabelingNutrition/ucm064916.htm.

21. Agência Nacional de Vigilância Sanitária (ANVISA). Portaria 27 de 1998: Aprova o Regulamento Técnico referente à Informação Nutricional Complementar (declarações relacionadas ao conteúdo de nutrientes) [cited 2014 Oct 12]. Available from: http://portal.anvisa.gov. br/wps/wcm/connect/9180ca00474581008d31dd3fbc4c6735/PORTARIA_27_1998.pdf?MOD=AJPERES.

22. Nilson EAF, Jaime PC, Resende DO. Iniciativas desenvolvidas no Brasil para a redução do teor de sódio em alimentos processados. Rev Panam Salud Publica 2012; 34(4):287-292.

23. Agência Nacional de Vigilância Sanitária (ANVISA). Mais sete grupos de alimentos terão redução de sódio. [cited 2014 Nov 28]. Available from: http://portal.anvia. gov.br/wps/portal/anvisa/anvisa/inprensa/!ut/p/c5/

24. Para Idec, metas de redução do sódio nos alimentos industrializados são brandas e não protegem a saúde da população. 2014 Aug 12. [cited 2015 Mar 13]. Available from: http://www.idec.org.br/em-acao/ em-foco/para-idec-metas-de-reduco-do-sodio-nos-alimentos-industrializados-so-brandas-e-no-protege-a-saude-da-populaco

25. Fitzpatrick L, Arcand J, Abbe ML, Deng M, Duhaney T, Campbell N. Accuracy of Canadian foodlabels for sodium content of food. Nutrient 2014; 6(8):3326-3335.

26. Ribeiro VF, Ribeiro MA, Vasconcelos MAS, Andrade SAC, Stamford TLM. Processed foods aimed at children and adolescent: Sodium content, adequacy according to the dietary reference intakes and label compliance. Rev Nutr 2013; 26(4):397-406.

27. Teste identifica 27 produtos com teores de sódio diferentes do informado. O Globo 2014 Jul 15 [cited 2016 Feb 23]. Available from: http://oglobo.globo.com/econo$\mathrm{mia} /$ defesa-do-consumidor/teste-identifica-27-produtos-com-teores-de-sodio-diferentes-do-informado-13265286.

28. Agencia Nacional de Vigilância Sanitária (ANVISA). Portaria No. 540 de 1997: Aprova o Regulamento Técnico: Aditivos Alimentares - definições, classificação e emprego. [cited 2014 Oct 12]. Available from: http://portal.anvisa.gov.br/wps/wcm/connect/d1b6da 0047457b4d880fdc3fbc4c6735/PORTARIA_540_1997. pdf?MOD=AJPERES.
29. Agencia Nacional de Vigilância Sanitária (ANVISA). Resolução RDC 27 de 2004: Aprova para Alimentos à Base de Cereais para Alimentação Infantil a extensão de uso de aditivos alimentares coadjuvantes de tecnologia [cited 2015 May 6]. Available from: http://portal.anvisa.gov.br/wps/wcm/connect/46fdlc0045a93a299b$219 \mathrm{fa} 9166895 \mathrm{f} 7 /$ Resolu\%C3\%A7\%C3\%A3o+RD$\mathrm{C}+\mathrm{n} \% \mathrm{C} 2 \% \mathrm{BA}+27 \% 2 \mathrm{C}+\mathrm{de}+13+$ de + fevereiro + de + 2004.pdf?MOD=AJPERES.

30. Agencia Nacional de Vigilância Sanitária (ANVISA). Resolução RDC 35 de 1998: Aprova para Alimentos de Transição para Lactentes e Crianças de Primeira Infância (Sopinha, Papinha, Purê e Suquinho) [cited 2015 May 6]. Available from: http://portal.anvisa.gov.br/ wps/content/Anvisa+Portal/Anvisa/Inicio/Alimentos/ Assuntos+de+Interesse/Legislacao/Aditivos+Alimentares+e+Coadjuvantes+de+Tecnologia

31. Agencia Nacional de Vigilância Sanitária (ANVISA). Resolução RDC 49 de 2014: Aditivos alimentares e coadjuvantes de tecnologia para fórmula infantis destinadas a lactentes e crianças de primeira infância [cited 2015 May 6]. Available from: http://portal.anvisa.gov.br/wps/ wcm/connect/cce20f0045d769598880ac7ffa9843d8/ Resolu\%C3\%A7\%C3\%A3o+RDC+49_2014_Altera+RDC+46_2011_.pdf?MOD=AJPERES.

32. Lorenzoni ASG, Oliveira FA, Cladera-Oliveira F. Food additives in products for children marketed in Brazil. Food and Public Health 2012; 2(5):131-136.

33. Coon JM. Medical view of additives and residues in foods. Am J Clin Nutr 1961; 9(3):288-296.

34. Carocho M, Barreiro MF, Morales P, Ferreira ICFR. Adding molecules to food, pros and cons: A review on synthetic and natural food additive. Comprehensive Reviews in Food Science and Food Safety 2014; 13(4):377399.

35. Binstok G, Campos C, Varela O, Gerschenson LN. Sorbate-nitrite reactions in meat products. Food Res Intl 1998; 31(8):581-585.

36. Ferrand C, Marc F, Fritsch P, Cassand P, Blanquat GS. Mutagenicity and genotoxicity of sorbic acid-amine reaction products. Toxicol In Vitro 2000; 14(5):423-428.

37. Mamur S, Yüzbasioglu D, Ünal F, Yilmaz S. Does potassium sorbate induce genotoxic or mutagenic effects in lymphocytes? Toxicol In Vitro 2010; 24(3):790-794.

38. Jung R, Cojocel C, Müller W, Böttger D, Lück E. Evaluation of the genotoxic potential of sorbic acid and potassium sorbate. Food Chem Toxicol 1992; 30:1-7.

39. Reinik M, Tamme T, Roasto M, Juhkam K, Jurtsenko S, Tenno T, Kiis A. Nitrites, nitrates and N-nitrosoamines in Estonian cured meat products: intake by Estonian children and adolescents. Food Addit Contam 2005; 22(11):1098-1105.

40. Melo-Filho AB, Biscontini TMB, Andrade SAC. Níveis de nitrito e nitrato em salsichas comercializadas na região metropolitana do Recife. Ciênc. Tecnol. Aliment 2004; 24(3):390-392.

41. Poul M, Jary G, Elhkim MO, Poul J. Lack of genotoxicity effect of food dyes amaranth, sunset yellow and tartrazine and their metabolites in the gut micronucleus assay in mice. Food Chem Toxicol 2009; 47:443-448.

42. Abramsson-Zetterberg L, Ilback NG. The synthetic food coloring agent Allura Red AC (E129) is not genotoxic in a flow cytometry-based micronucleus assay in vivo. Food Chem Toxicol 2013; 59:86-89. 
43. Tsuda S, Murakami M, Matsusaka N, Kano K, Taniguchi K, Sasaki YF. DNA damage induced by red food dyes orally administered to pregnant and male mice. Toxicol Sci 2001; 61(1):92-99.

44. Lucová M, Hojerová S, Klimová Z. Absorption of triphenylmethane dyes brilliant blue and patent blue through intact skin, shaven skin and lingual mucosa from daily life products. Food Chem Toxicol 2013; 52:19-27.

45. Piasini A, Stulp S, Dal Bosco SM, Adami FS. Análise da concentração de tartrazina em alimentos consumidos por crianças e adolescentes. Revista Uningá Review 2014; 19(1):14-18.

46. National Toxicology Program (NTP). Technical Report on the Toxicology and Carcinogenesis Studies of 4-Methylimidazole (CAS No. 822-36-6) in F344/N Rats and B6C3F1 Mice (Feed Studies). 2007. [cited 2015 Nov 15]. Available: http://ntp.niehs.nih.gov/ntp/htdocs/LT_rpts /tr535.pdf.

47. Food and Drug Administration (FDA). Questions and answers on caramel coloring and 4-MEI. [cited 2016 Jan 15]. Available from: http://www.fda.gov/food/ingredientspackaginglabeling/foodadditivesingredients/ ucm364184.htm.

48. Agencia Nacional de Vigilância Sanitária (ANVISA). Informe Técnico $\mathrm{N}^{\circ} 48$ de 10 de Abril de 2012. [cited 2015 Oct 28]. Available from: http://portal.anvisa.gov. br/documents/33916/388729/Informe_Tecnico_n_48_ de_10_de_abril_de_2012.pdf/18078a63-fbb0-42e9b01a-b72601b5b159.

49. Yang WH, Drouin MA, Herbert M, Mao Y, Karsh J. The monosodium glutamate symptoms complex: assessment in double-blind, placebo-controlled, randomized study. J Aller Clin Immunol 1997; 99(6 Pt 1):757-762.

50. Agencia Nacional de Vigilância Sanitária (ANVISA). Resolução RDC 45 de 2010: Aditivos alimentares autorizadospara uso segundo as Boas Práticas de Fabricação (BPF) [cited 2015 Sep 30]. Available from: http://portal.anvisa.gov.br/wps/wcm/connect/11707300474597459fc3df3fbc4c6735/Resolu\%C3\%A7\%C3\%A3o+da+Diretoria+Colegiada++RDC $+\mathrm{n}++45+\mathrm{de}+03+\mathrm{de}+$ no vembro+de+2010.pdf?MOD=AJPERES.

Artigo apresentado em 30/03/2016

Aprovado em 25/10/2016

Versão final apresentada em 27/10/2016 
